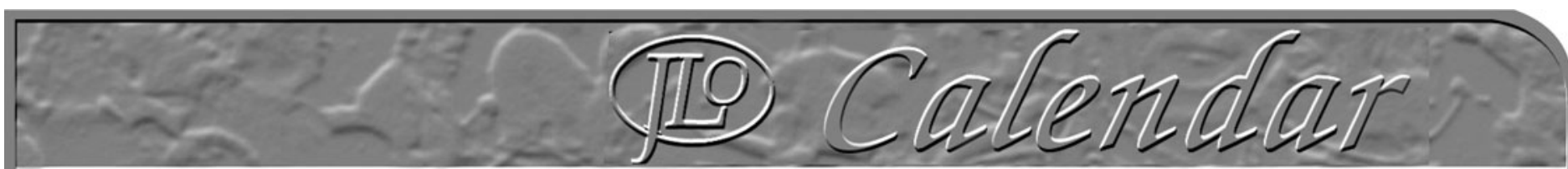

\title{
EVENTS, COURSES AND CONFERENCES
}

\section{0}

\section{August}

22nd International Course on

Endoscopic Surgery of the Paranasal Sinuses

August 18-21, 2010

Ghent, Belgium

Contact: Prof. C. Bachert

E-mail: petra.vandewalle@ugent.be

Glasgow University Temporal Bone Rhinology Head and Neck Intensive

Dissection Course

August 25-27, 2010

Glasgow, $U K$

Contact: Mr B. O'Reilly

E-mail: brian.o'reilly@ggc.scot.nhs.uk

\section{September}

15th Dundee Advanced Rhinoplasty

Skills Course Open Structure

Rhinoplasty

September 1-3, 2010

Dundee, Scotland

Contact: Mrs L. Warden

rden@dundee.ac.uk

Website: www.dundee.ac.uk/otolaryngology

8th Congress of European

Laryngological Society

September 1-4, 2010

Vienna, Austria

Contact: Marc Remacle

Website: www.elsoc.org

The 17th Annual Endoscopic Nasal \&

Paranasal Sinus Surgery Course

September 6-8, 2010

Glasgow, UK

Contact: Mrs Anne Byrne

Tel: + $44(0) 1412015478$

E-mail: anne.byrne@gac.scotnhs.uk

The 4th World Voice

Congress

September 6-9, 2010

Seoul, Korea

Contact: Secretariat

Tel: +8225666067

Fax: + 8225666087

E-mail: seoul@voice2010.org

Website: www.voice2010.org

\section{ENT UK Annual Meeting}

September 10, 2010

London, UK

Website: www.entuk.org
British Society of Otology Anglo

Swedish Meeting

September 11-12, 2010

Oxford, UK

Website: www.entuk.org

2010 Temporal Bone Surgical

Dissection 5 Day Course

September 13-17, 2010

Michigan, USA

E-mail: leldred@umich.edu/oto

18th Annual Conference on

Management of the Tinnitus Patient

September 16-18, 2010

Iowa City, USA

Tel: + 18005519029

British Association for Paediatric

Otorhinolaryngology Academic

Meeting

September 17, 2010

Stratford upon Avon, UK

Website: www.entuk.org

114th American Academy of ORL,

Head \& Neck Surgery Annual

Meeting \& OTO EXPO

September 26-29, 2010

Boston, USA

Contact: Marketing Co-ordinato

E-mail: aaomeet@entnet.org

Website: www.entnet.org

\section{October}

Current Concepts in Head and Neck Surgery and Oncology

October 3-5, 2010

Frankfurt, Germany

Website: www.ifhnosworldtour2010.org

\section{5th EUHA Congress}

October 13-15, 2010

Hanover, Germany

Tel: + 49 (0) 61 31/28 30-0

E-mail: info@euha.org

Website: euha.org

10th International Rhinoplasty

and Cosmetic Facial Surgery

Workshop

October 27-30, 2010

Bangkok, Thailand

Email: baserbv@gmail.com

\section{November}

22nd Literature Evaluation and

Research in ORL

November 3-4, 2010

London, UK

Contact: Mr I.R.C. Swan

E-mail: iain@ihr.gla.ac.uk
South Western Otolaryngological

Association Winter Meeting

November 10, 2010

Bristol, UK

Contact: Eva Hicks

E-mail: eva.hicks@nbt.nhs.uk

British Academy of Audiology

Annual Conference

November 10-12, 2010

Edinburgh, UK

Website: www.baaudiology.org

Courses on Middle Ear and Lateral

Skull Base Surgery

November 22-26, 2010

Piacenza, Italy

Contact: Secretary Gruppo Otologico

E-mail: corsi_sanna@gruppootologico.it

19th Annual Conference of Indian

Society of Otology

November 26-28, 2010

Nagpur, India

E-mail: isocon2010nagpur@hotmail.com

Tel: + 9107122460868

\section{1}

\section{March}

12th Asia-Oceania ORL-HNS

Conference

March 1-4, 2011

Auckland, New Zealand

Tel: + 6493601240

E-mail: asia-oceania@tcc.co.nz

\section{June}

10th European Federation of

Audiology Societies and 6th Annual

Conference of the Audiology and

Phoniatrics Section of the Polish

Society

June 22-26, 2011

Warsaw, Poland

Website: efas2011.org

\section{July}

1st Congress of the Confederation of European Otorhinolaryngology,

Head \& Neck Surgery

July 2-6, 2011
Barcelona, Spain

Website: www.ceorlhnsbarcelona2011.org

\section{September}

ENT UK Annual Meeting

September 9, 2011

London, UK

Website: www.entuk.org

\section{2}

\section{May}

12th International Conference on Cochlear Implants and other

Implantable Auditory Technologies May 3-5, 2012

Baltimore, USA

E-mail: corinnea@cmcglobal.com

Website: ci-2012.com

11th International Congress of the European Society of Pediatric

Otorhinolaryngology

May 20-23, 2012

Amsterdam, The Netherland

Website: www.espo2012.com

\section{June}

24th Congress of the European Rhinologic Society

June 17-21, 2012

Toulouse, France

Contact: Organisation Committee, Europ

Tel: + 33534452645

E-mail: registers@europa-organisation.com

\section{July}

BACO 2012

July 4-6, 2012

Glasgow, UK

Website: entuk.org

14th British Academic Conference in Otolaryngology

July 3-6, 2012

Glasgow, UK

E-mail:admin@entuk.org

Website: www entuk.org 


\title{
ए7 MAYO CLINIC
}

\author{
Mayo Clinic Florida \\ James and Martha Crawford Endowment \\ Research Fellowship Opportunity \\ July 1, 2011 - June 30, 2012
}

Mayo Clinic Florida offers a one-year clinical research (non-patient contact) fellowship opportunity in Otolaryngology. Our tertiary care program covers advanced Head \& Neck Surgery, Rhinology/ Sinus Surgery, Otology \& Neurotology, and Laryngology. This fellowship is designed to offer a senior resident in training and/or junior faculty the opportunity to enhance and develop clinical research skills (study design, database development, statistics, publications, presentations, etc).

For more information please visit:

www.mayo.edu/ent-fellowship

4500 San Pablo Road, Jacksonville, FL 32224 Phone: 904-953-0468

Email: entfellowshipinfo@mayo.edu

\section{CAMBRIDGE}

\section{JUURALS}

\section{Bulk Article Reprints}

Reprints of articles published in this journal can be purchased for use by your company or organisation. These reprints can be produced as straight article reprints or with custom designed covers and, if required, the sponsor's name printed on or inside the cover. Reprints represent a versatile sales tool for the distribution of up-to-date information on your particular areas - via your sales force, direct mail campaigns and as handouts at major conferences and commercial exhibitions. Reprints can usually be delivered to clients $2-4$ weeks after the receipt of the order.

\section{Rebecca Curtis, Special Sales Manager}

Cambridge University Press, The Edinburgh Building,

Shaftesbury Road, Cambridge, UK, CB2 8RU

Tel: +44 (0)1223 325757, Email: special_sales@cambridge.org

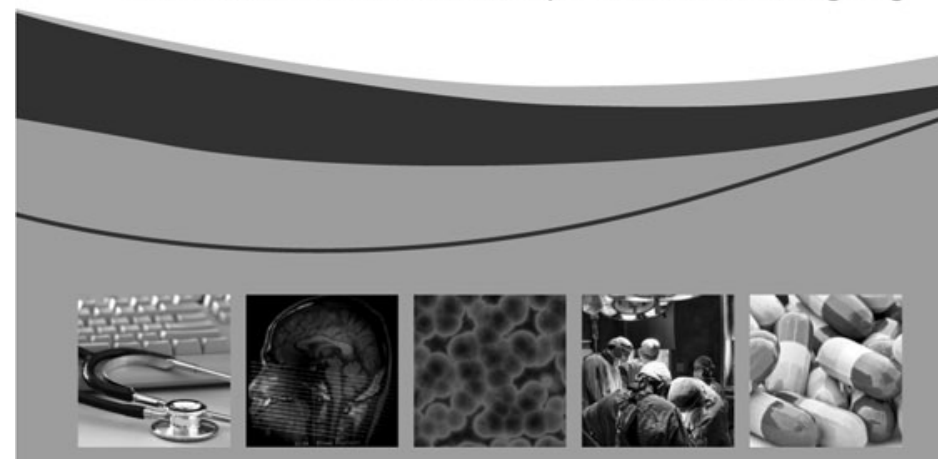




\section{The Journal of Laryngology \& Otology}

Review Article

The future of early disease detection? Applications of electronic nose technology in otolaryngology: N Charaklias, H Raja, ML Humphreys, N Magan, CA Kendall

\section{Main Articles}

Cochlear implant patients' speech understanding in background noise: effect of mismatch between electrode assigned frequencies and perceived pitch: W Di Nardo, A Scorpecci, S Giannantonio, F Cianfrone, C Parrilla, G Paludetti

Quality of life in patients with untreated age-related hearing loss: HS Chew, S Yeak

Combined tympanic epithelial layer avulsion and overlay myringoplasty for diffuse granular myringitis: $Z$ Zhang, $X$ Liu, S Chen, $Y$ Zheng

Malignant otitis externa: case series: T Ali, K Meade, S Anari, MR ElBadawey, I Zammit-Maempel 846

Vestibular substitution: comparative study: $S$ Polat, A Uneri

Influence of compact disk recording protocols on reliability and comparability of speech audiometry outcomes: acoustic analysis: F Di Berardino, G Tognola, A Paglialonga,

D Alpini, F Grandori, A Cesarani

Customised acrylic nasal stents following recanalisation of modified Young's procedure: P Pavithran, K Pujary, SG Mahesh, P Parul, B Aziz

Outcome of surgical closure of nasal septal perforation: $S$ Wong, U Raghavan

Evaluation of computed tomography virtual bronchoscopy in paediatric tracheobronchial foreign body aspiration: KV Bhat, JS Hegde, US Nagalotimath, GC Patil

Double-blind, randomised, controlled study of post-operative pain in children undergoing radiofrequency tonsillotomy versus laser tonsillotomy: K Stelter, $R$ De La Chaux, $M$ Patscheider, B Olzowy

Selective lateral laser thyroarytenoid myotomy for adductor spasmodic dysphonia: A Hussain, M Shakeel

Protection of high-riding aberrant innominate artery during open tracheotomy: $A$ Netzer, D Ostrovsky, R Bar, ST Westerman, A Golz

Holmium:YAG laser: 12-year study of indications for use and outcomes in benign and malignant otolaryngological conditions: J Joseph, M-C Jaberoo, M Dilkes

Changes in surgical consent practices for common otolaryngology procedures: impact of Modernising Medical Careers: P Puwanarajah, SE McDonald

\section{Short Communications}

New repositioning techniques for benign paroxysmal positional vertigo: the Li repositioning manoeuvres: $J \mathrm{Li}, \mathrm{H} \mathrm{Li}$

Single, subcondylar mandibular osteotomy: a new access route for extensive, benign parapharyngeal neoplasms: B Bianchi, A Ferri, S Ferrari, C Copelli, AS Magri, E Sesenna

Clinical Records

Diagnostic challenges in tuberculous otitis media: IP Tang, N Prepageran, CA Ong, P Puraviappan

Internal jugular vein thrombosis secondary to a permanent cardiac pacemaker: an unusual case of lateral neck swelling: CS Arhi, MA Buchanan, SA Allen, J Pickles

Resolution of hyperacusis associated with depression, following lithium administration and directive counselling: D Attri, AN Nagarkar

An unusual case of cotton wool use to improve hearing: M Bergin, D Murray, P Bird

A rare cause of Horner syndrome: D Costello, J Salmon, C Milford, P Pretorius

Cavernous sinus thrombosis secondary to contralateral sphenoid sinusitis: a diagnostic challenge: A Eweiss, W Mukonoweshuro, HS Khalil

Enlarged internal auditory canal and sudden deafness: G Magliulo, A Stasolla, MG Colicchio, $S$ Gagliardi

Nasal and ophthalmomyiasis: case report: I Smillie, PKS Gubbi, HC Cocks

Anterior spinal artery syndrome: a rare complication of head and neck surgery: $C$ Gadepalli, A Cardozo, S Loughran 